\title{
Ice cores from Arctic sub-polar glaciers: chronology and post-depositional processes deduced from radioactivity measurements
}

\author{
Jean Frangis PINGLOT, ${ }^{1}$ Rein A. VAIKMÄE, ${ }^{2}$ Kокighi KAMIYAMA, ${ }^{3}$ Makoto IGARASHI, ${ }^{3}$ \\ Diedrigh FRITZSCHE, ${ }^{4}$ Frank WILHELMS, ${ }^{5}$ Roy KOERNER,${ }^{6}$ Lori HENDERSON, \\ Elisabeth ISAKSSON, ${ }^{8}$ Jan-Gunnar WINTHER,${ }^{8}$ Roderik S.W.VAN DE WAL, ${ }^{9}$ \\ Marc FOURnieR, ${ }^{10}$ Patrigk BOUISSET ${ }^{10}$ Harro A.J. MEIJER ${ }^{11}$ \\ ${ }^{1}$ Laboratoire de Glaciologie et Géophysique de l'Environnement, CNRS, BP 96, 38402 Saint Martin d'Hères Cedex, France \\ E-mail:pinglot@lgge.obs.ujf-grenoble.fr \\ ${ }^{2}$ Institute of Geology, Tallinn Technical University, 7 Estonia Avenue, EE-10143 Tallinn, Estonia \\ ${ }^{3}$ Meteorological and Glaciological Section, National Institute of Polar Research, 1-9-10 Kaga 1-chome, Itabashi-ku, Tokyo 173-8515, Japan \\ ${ }^{4}$ Alfred-Wegener Institute for Polar and Marine Research, P.O. Box 600149, D-14473 Potsdam, Germany \\ ${ }^{5}$ Alfred-Wegener Institute for Polar and Marine Research, P.O. Box 120161, D-27515 Bremerhaven, Germany \\ ${ }^{6}$ Glaciology Section, Terrain Sciences Division, Geological Survey of Canada, 601 Booth Street, Ottawa, Ontario K1A 0E8, Canada \\ ${ }^{7}$ Department of Earth Sciences, University of Ottawa, 140 Louis Pasteur, Ottawa, Ontario K1N 6N5, Canada \\ ${ }^{8}$ Norwegian Polar Institute, Polar Environmental Centre, N-9296 Tromso, Norway \\ ${ }^{9}$ Institute for Marine and Atmospheric Research, Utrecht University, Princetonplein 5, 3584 CC Utrecht, The Netherlands \\ ${ }^{10}$ Institut de Protection et de Sûreté Nucléaire, DPRE, SERNAT, LMRE-Orsay, Bât. 501, Bois des Rames, 91400 Orsay Cedex, France \\ ${ }^{11}$ Centre for Isotope Research, University of Groningen, Nijenborgh 4, 9747 AG Groningen, The Netherlands
}

\begin{abstract}
The response of Arctic ice masses to climate change is studied using ice cores containing information on past climatic and environmental features. Interpretation of this information requires accurate chronological data. Absolute dating of ice cores from sub-polar Arctic glaciers is possible using well-known radioactive layers deposited by atmospheric nuclear tests (maximum fallout in 1963) and the Chernobyl accident (1986). Analysis of several isotopes $\left({ }^{3} \mathrm{H},{ }^{137} \mathrm{Cs}\right)$ shows that ${ }^{3} \mathrm{H}$ provides the most accurate dating of the 1963 maximum, as indicated also in comparison with results from total-beta measurements $\left({ }^{90} \mathrm{Sr}\right.$ and $\left.{ }^{137} \mathrm{Cs}\right)$. Mean annual net mass balances are derived from the dated ice cores from 1963 up to the date of the drillings. The ${ }^{137} \mathrm{Cs}$ and ${ }^{3} \mathrm{H}$ deposited by nuclear tests, after decay correction, are used to define a melt index for all 13 ice cores studied. The relative strength of melting and percolation post-depositional processes is studied on the basis of these ${ }^{137} \mathrm{Cs}$ and ${ }^{3} \mathrm{H}$ deposits.
\end{abstract}

\section{INTRODUGTION}

This study is mostly concerned with the dating of ice cores from Arctic sub-polar glaciers and small ice caps, not including the cold snow layers of the Greenland plateau. Both melting and percolation occur at these locations and consequently dating based on stratigraphy or the annual variation of key parameters (stable isotopes, major ionic species, etc.) can be very uncertain. However, these ice cores can be dated accurately on the basis of well-known radioactive layers originating from past atmospheric nuclear tests (1954-74), and nuclear accidents (Chernobyl, 1986). Past volcanic events (e.g. Lakagigar Island, 1783 or Bezymianny-Kamtchatka, 1956) can in some cases substantiate the chronology obtained using these radioactive markers (Fritzsche and others, 2002).

The aim of this study is to compare chronologies determined using different radioactivity profiles for ice cores retrieved from several glaciers in the high-Arctic area. Artificial isotopes from nuclear tests $\left({ }^{3} \mathrm{H}\right.$ and $\left.{ }^{137} \mathrm{Cs}\right)$ were analyzed along with natural isotopes (mainly ${ }^{210} \mathrm{~Pb}$ ). These chronologies allow us to compare the behaviour of the different isotopes when subjected to post-depositional processes, in particular melting and percolation (and wind scouring for the Chernobyl layer), as studied by Prantl and others (1973). The extent of these processes is estimated for each ice core studied. After correcting for the 1963 mean fall-out date or the absolute date of each snow layer, a melt index can be derived giving the relative magnitude of the melting and percolation processes. These ice-core chronologies can be used to determine the mean annual net mass balance (MANMB) from 1963 to the date of the drillings. The fall-out of ${ }^{3} \mathrm{H}$ and ${ }^{137} \mathrm{Cs}$ is studied over an archipelago (Svalbard, Norway) and over the Arctic area. We have used the Chernobyl layer extensively in previous studies for absolute dating of shallow ice cores (Lefauconnier and others, 1994; Pinglot and others, 1994, 1999, 2001).

\section{STUDY AREA - PREVIOUS WORK}

We have studied the distribution of natural and artificial radio-isotopes (from atmospheric nuclear tests and the 

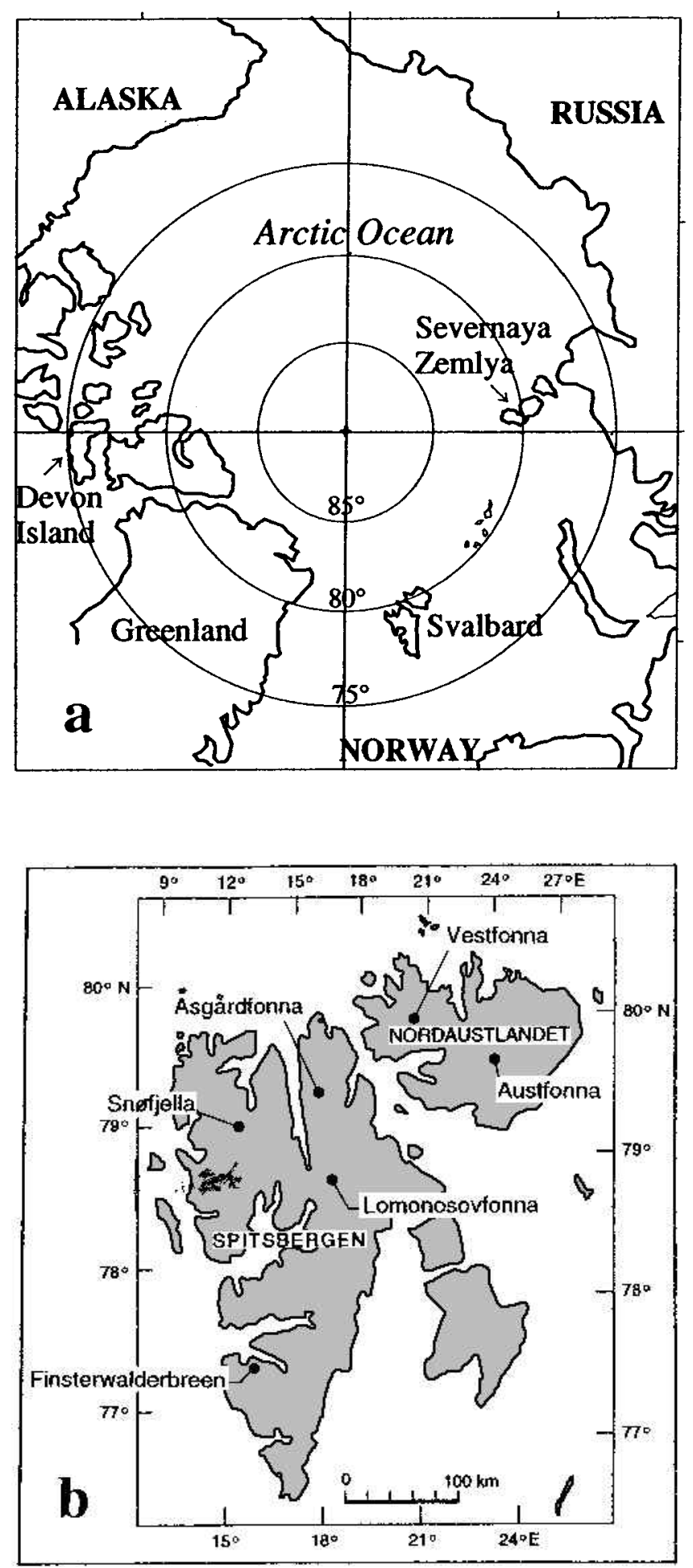

Fig. 1. Maps of the high Arctic ( a) and Svalbard (b) showing ice-core locations.

Chernobyl accident) in ice cores retrieved from high-Arctic glaciers, in particular from Devon Island (Canada), Svalbard (Norway) and Severnaya Zemlya (Russia) (Fig. la). Radioactivity was measured in samples from 13 ice cores (Table 1 , see also for name abreviations) containing deposits from the atmospheric nuclear tests (from 1954-74). Eleven of the ice cores were drilled in Svalbard: Snøfjella (Goto-Azuma and others, 1995); Åsgårdfonna (Uchida and others, 1996); Finsterwalderbreen (Pinglot and others, 1997); Lomonosovfonna in 1997 (Isaksson and others, 2001) and 2000; and on Nordaustlandet, respectively, at Vestfonna in 1981 (Punning and others, 1986) and Austfonna in 1985 and 1987 by former Soviet Union

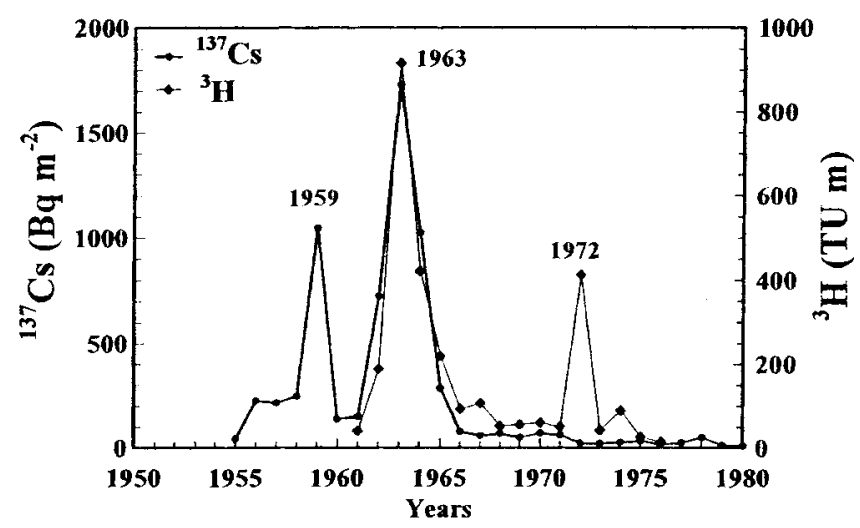

Fig. 2. ${ }^{137}$ Cs fall-out at Tromsø and ${ }^{3} \mathrm{H}$ content in fall-out at Isfjord Radio from atmospheric nuclear tests.

drilling teams (Tarussov, 1992); and at Vestfonna in 1995 and Austfonna in 1998 and 1999 by the Japanese National Institute of Polar Research (Watanabe and others, 2001) (Fig.1b).

Complementary ice cores from the high Arctic were recovered from Devon Ice Cap, Devon Island, Nunavut, Canada, in 1998 and from Akademii Nauk ice cap, Severnaya Zemlya, Eurasian Arctic, in 1999 and 2000 (Fritzsche and others, 2002) (Table 1). The ice cores were sampled from the surface to 30-40 m depth, depending on the location, for measurements of radioactivity. Ten of the ice cores were analyzed for both ${ }^{137} \mathrm{Cs}$ and ${ }^{3} \mathrm{H}$ from nuclear tests and ${ }^{210} \mathrm{~Pb}$, while three cores were analyzed only for ${ }^{137} \mathrm{Cs}$ and ${ }^{210} \mathrm{~Pb}$.

\section{ARTIFICIAL AND NATURAL RADIOAGTIVITY}

Artificial radioactivity in Arctic glaciers is mainly related to the atmospheric nuclear tests conducted from 1954 (the beginning of atmospheric fall-out) to 1974. The maximum radioactivity in the Arctic occurred in 1963 (UKAEA, 195797; Theodórsson, 1977; IAEA, 1984) (Fig. 2). This was due to nuclear tests conducted in September-November 1961 at Semipalatinsk $\left(50^{\circ} \mathrm{N}, 80^{\circ} \mathrm{E}\right.$; $120 \mathrm{MtTNTeq}$ ) and in AugustDecember 1962 at Novaya Zemlya $\left(71-73^{\circ} \mathrm{N}, 55^{\circ} \mathrm{E}\right.$; $180 \mathrm{MtTNTeq.)}$ (Aarkrog and others, 1994). The long-lived products from these events are ${ }^{137} \mathrm{Cs}$ (half-life of 30.15 years), ${ }^{90} \mathrm{Sr}$ (28.15 years) and ${ }^{3} \mathrm{H}$ (12.34 years) as well as transuranic elements (not studied in this paper).

In order to compare the radioactivity profiles measured in ice cores with the original atmospheric signals, Figure 2 includes ${ }^{137}$ Cs fall-out at Tromsø, Norway, for 1955-80 (Wright and others, 1999) and ${ }^{3} \mathrm{H}$ fall-out, expressed in TUm, at Isfjord Radio, Svalbard, for 1961-76 (1 TU $\left.\equiv 0.118 \mathrm{~Bq} \mathrm{~kg}^{-1}\right)$. Both profiles reflect the atmospheric nuclear tests. These locations are quite close to the high-Arctic glaciers, so they clearly indicate transfer from the atmosphere to the snow layers. The ${ }^{137}$ Cs record exhibits a first peak in 1959, and a maximum peak in 1963. Tritium was not monitored in Svalbard before 1961. ${ }^{3} \mathrm{H}$ also peaked in 1959 and 1963. A peak of ${ }^{3} \mathrm{H}$ fall-out (about ten times the annual natural average) also occurred at Isfjord Radio in 1972, a year with a high annual precipitation feature with twice the mean value (IAEA, 1984). As discussed below, this ${ }^{3} \mathrm{H}$ peak in 1972 has not been detected in studies of high-Arctic ice cores from the Greenland ice sheet (Koide and others, 1982), Mount Logan, Yukon Territory, Canada (Holdsworth and others, 1984) and Agassiz Ice Cap, Ellesmere Island, Canada (Kotzer and others, 2000). 
Table 1. Locations of 13 ice cores retrieved from the high Arctic

\begin{tabular}{|c|c|c|c|c|c|c|}
\hline \multirow[t]{2}{*}{ Areas } & \multirow[t]{2}{*}{ Glacier names } & \multirow{2}{*}{$\begin{array}{c}\text { Ice cores } \\
\text { (Drilling year) }\end{array}$} & \multicolumn{2}{|c|}{ Coordinates } & \multirow{2}{*}{$\begin{array}{l}\text { Altitude } \\
\text { ma.s.l. }\end{array}$} & \multirow[t]{2}{*}{ Sources } \\
\hline & & & Longitude & Latitude & & \\
\hline \multirow[t]{11}{*}{ Svalbard } & Vestfonna & Ves81 (1981) & $79^{\circ} 56^{\prime} \mathrm{N}$ & $19^{\circ} 31^{\prime} \mathrm{E}$ & 580 & Punning and others (1986) \\
\hline & & Ves95 (1995) & $79^{\circ} 58^{\prime} \mathrm{N}$ & $21^{\circ} 01^{\prime} \mathrm{E}$ & 600 & \\
\hline & Austfonna & Aus85 (1985) & $79^{\circ} 50^{\prime} \mathrm{N}$ & $24^{\circ} 08^{\prime} \mathrm{E}$ & $783^{*}$ & \\
\hline & & Aus87 (1987) & $79^{\circ} 50.6^{\prime} \mathrm{N}$ & $24^{\circ} 08.02^{\prime} \mathrm{E}$ & $783^{*}$ & Tarussov (1992) \\
\hline & & Aus98 (1998) & $79^{\circ} 48^{\prime} \mathrm{N}$ & $24^{\circ} 00^{\prime} \mathrm{E}$ & 758 & \\
\hline & & Aus99 (1999) & $79^{\circ} 50^{\prime} \mathrm{N}$ & $24^{\circ} 00^{\prime} \mathrm{E}$ & 783 & \\
\hline & Snøfjella & Sno92 (1992) & $79^{\circ} 08^{\prime} \mathrm{N}$ & $13^{\circ} 17^{\prime} \mathrm{E}$ & 1190 & Goto-Azuma and others (1995) \\
\hline & Åsgårdfonna & Asg93 (1993) & $79^{\circ} 26^{\prime} 38^{\prime \prime} \mathrm{N}$ & $16^{\circ} 42^{\prime} 3^{\prime \prime} \mathrm{E}$ & 1140 & Uchida and others (1996) \\
\hline & Finsterwalderbreen & Fin94 (1994) & $77^{\circ} 25^{\prime} 46^{\prime \prime} \mathrm{N}$ & $15^{\circ} 18^{\prime} 12^{\prime \prime} \mathrm{E}$ & 668 & \\
\hline & Lomonosovfonna & Lom97 (1997) & $78^{\circ} 51^{\prime} 53^{\prime \prime} \mathrm{N}$ & $17^{\circ} 25^{\prime} 30^{\prime \prime} \mathrm{E}$ & 1250 & Isaksson and others (2001) \\
\hline & & Lom00 (2000) & $78^{\circ} 51^{\prime} 48^{\prime \prime} \mathrm{N}$ & $17^{\circ} 25^{\prime} 18^{\prime \prime} \mathrm{E}$ & 1250 & \\
\hline Severnaya Zemlya & Akademii Nauk ice cap & Sev99 (1999) & $80^{\circ} 31^{\prime} \mathrm{N}$ & $94^{\circ} 49^{\prime} \mathrm{E}$ & 765 & Fritzsche and others (2002) \\
\hline Arctic Canada & Devon Ice Cap & Dev98 (1998) & $75^{\circ} 00^{\prime} \mathrm{N}$ & $82^{\circ} 00^{\prime} \mathrm{W}$ & 1800 & Koerner and Taniguchi (1976) \\
\hline
\end{tabular}

\footnotetext{
* Best estimated values.
}

More recently (26 April 1986), the Chernobyl accident also spread ${ }^{137} \mathrm{Cs}$ all over the Northern Hemisphere glaciers (Pourchet and others, 1988). Both nuclear tests and the Chernobyl accident occurred in the Northern Hemisphere and most Arctic ice caps and glaciers received the corresponding fall-out (Pinglot and others, 1994).

Natural radioactivity comes from ${ }^{210} \mathrm{~Pb}$ (half-life of 22 years), a decay product of ${ }^{238} \mathrm{U}$. When the parent isotope $\left({ }^{238} \mathrm{U}\right.$ ) disintegrates to ${ }^{226} \mathrm{Ra},{ }^{222} \mathrm{Rn}$ (a noble gas) escapes from the soil. This isotope, after several short-lived disintegration processes, gives rise to ${ }^{210} \mathrm{~Pb}$ and tends to reach a secular equilibrium in the atmosphere. ${ }^{7} \mathrm{Be}$ (53.6 days) originating from cosmic rays, is another natural isotope found in glaciers.

Both artificial and natural isotopes are deposited on the snow surface mainly by washout and to a lesser extent by dry fall-out (Pinglot and others, 2001).

\section{SAMPLING AND ANALYTICAL METHODS}

All ice-core samples were collected using shallow or deep electromechanical drilling equipment. Sub-samples for radioactivity measurements came from the surface down to about $40 \mathrm{~m}$ (maximum depth corresponding to the first fallout from atmospheric nuclear tests). The length of each sample varied from 5-200 cm, depending on the ice-core location and the measured isotope (Table 2). In order to obtain an age-scale equivalent, snow depths were converted to depths expressed in metres of water equivalent (m w.e.), using the densification of snow with depth.

The ${ }^{3} \mathrm{H}$ analysis was conducted on melted sub-samples ( $5 \mathrm{~cm}$ long), followed by liquid-scintillation counting. The 1997 Lomonosovfonna profile was measured using low-level proportional counters, for which technique a sample amount of only $5 \mathrm{~mL}$ suffices. Therefore, the spatial resolution of this specific profile could be higher.

Total-beta measurements were carried out on melted samples filtered through ion-exchange papers (Delmas and Pourchet, 1977; Pinglot and Pourchet, 1979) and include ${ }^{90} \mathrm{Sr}$, ${ }^{137} \mathrm{Cs}$ and ${ }^{210} \mathrm{~Pb}$ cations, which are insoluble particulates. All the above-described isotopes emit beta rays $\left({ }^{3} \mathrm{H}\right.$ and ${ }^{90} \mathrm{Sr}$ are pure beta emitters). The total-beta-radioactivity measurement of snow samples from ice cores is the amount of both artificial and natural isotopes, without any possible discrimination. In Svalbard glaciers and in other locations in the Arctic, artificial and natural radioactivity are of equivalent magnitudes. This explains why the total-betacounting technique is not always valid for the detection of the 1963 or Chernobyl layers.

In order to properly quantify ${ }^{137} \mathrm{Cs}$ and ${ }^{210} \mathrm{~Pb}$, we used high-resolution gamma-ray spectrometry. Our equipment is designed to detect very low levels of radioactivity, including a 20\% high-purity Ge (N-type) detector, with an antiCompton scintillation detector (Pinglot and Pourchet, 1994). The detection levels for ${ }^{137} \mathrm{Cs}$ and ${ }^{210} \mathrm{~Pb}$ are 4 and $10 \mathrm{mBq}$, respectively, for 3 day measurements with a $97.5 \%$ confidence level. ${ }^{137} \mathrm{Cs}$ and ${ }^{210} \mathrm{~Pb}$ are measured at the same time.

Table 2. Depths ( $m$ w.e.) of the 1963 layer, from ${ }^{3} \mathrm{H}$ and ${ }^{137} \mathrm{Cs}$, for ten ice cores, with corresponding depth and dating differences

\begin{tabular}{|c|c|c|c|c|c|c|c|c|}
\hline \multirow[t]{2}{*}{$\begin{array}{l}\text { Ice } \\
\text { cores }\end{array}$} & \multirow{2}{*}{$\begin{array}{c}\text { Sample } \\
\text { length } \\
\text { mw.e. }\end{array}$} & \multirow[t]{2}{*}{ Isotopes } & \multicolumn{3}{|c|}{1963 depth } & \multicolumn{2}{|c|}{$\begin{array}{l}\text { Depth difference } \\
{ }^{137} \mathrm{Cs} \text { to }{ }^{3} \mathrm{H}\end{array}$} & \multirow{2}{*}{$\begin{array}{c}\text { Dating } \\
\text { difference } \\
\text { years }\end{array}$} \\
\hline & & & m w.e. & m w.e. & m w.e. & $\mathrm{m}$ & mw.e. & \\
\hline \multirow[t]{2}{*}{ Ves81 } & 0.54 & ${ }^{3} \mathrm{H}$ & 5.67 & 6.21 & 5.94 & \multirow[t]{2}{*}{0.67} & \multirow[t]{2}{*}{0.51} & \multirow[t]{2}{*}{1.56} \\
\hline & 0.91 & ${ }^{137} \mathrm{Cs}$ & 6.00 & 6.91 & 6.45 & & & \\
\hline \multirow[t]{2}{*}{ Ves95 } & 1.20 & ${ }^{3} \mathrm{H}$ & 10.86 & 12.06 & 11.46 & \multirow[t]{2}{*}{0.81} & \multirow[t]{2}{*}{0.72} & \multirow[t]{2}{*}{1.99} \\
\hline & 0.91 & ${ }^{137} \mathrm{Cs}$ & 11.83 & 12.52 & 12.17 & & & \\
\hline \multirow[t]{2}{*}{ Aus85 } & 0.37 & ${ }^{3} \mathrm{H}$ & 9.42 & 9.79 & 9.60 & \multirow[t]{2}{*}{0.80} & \multirow[t]{2}{*}{0.72} & \multirow[t]{2}{*}{1.64} \\
\hline & 0.88 & ${ }^{137} \mathrm{Cs}$ & 9.88 & 10.76 & 10.32 & & & \\
\hline \multirow[t]{2}{*}{ Aus98 } & 0.22 & ${ }^{3} \mathrm{H}$ & 15.75 & 15.97 & 15.86 & \multirow[t]{2}{*}{0.12} & \multirow[t]{2}{*}{0.11} & \multirow[t]{2}{*}{0.25} \\
\hline & 0.44 & ${ }^{137} \mathrm{Cs}$ & 15.75 & 16.19 & 15.97 & & & \\
\hline \multirow[t]{2}{*}{ Aus99 } & 0.37 & ${ }^{3} \mathrm{H}$ & 15.70 & 16.07 & 15.88 & \multirow[t]{2}{*}{0.00} & \multirow[t]{2}{*}{0.00} & \multirow[t]{2}{*}{0.00} \\
\hline & 0.37 & ${ }^{137} \mathrm{Cs}$ & 15.70 & 16.07 & 15.88 & & & \\
\hline \multirow[t]{2}{*}{ Sno92 } & 0.13 & ${ }^{3} \mathrm{H}$ & 12.06 & 12.18 & 12.12 & \multirow[t]{2}{*}{0.50} & \multirow[t]{2}{*}{0.44} & \multirow[t]{2}{*}{0.94} \\
\hline & 1.76 & ${ }^{137} \mathrm{Cs}$ & 11.68 & 13.44 & 12.56 & & & \\
\hline \multirow[t]{2}{*}{ Asg93 } & 0.38 & ${ }^{3} \mathrm{H}$ & $9.02^{*}$ & $10.04^{*}$ & 9.53 & \multirow[t]{2}{*}{$0^{*}$} & \multirow[t]{2}{*}{$0^{*}$} & \multirow[t]{2}{*}{$0^{*}$} \\
\hline & 0.38 & ${ }^{137} \mathrm{Cs}$ & 9.02 & 10.04 & 9.53 & & & \\
\hline Lom97 & 0.04 & ${ }^{3} \mathrm{H}$ & 12.88 & 13.08 & 12.98 & -0.10 & -0.07 & -0.21 \\
\hline & 0.35 & ${ }^{137} \mathrm{Cs}$ & 12.73 & 13.08 & 12.90 & & & \\
\hline Lom00 & 0.38 & ${ }^{3} \mathrm{H}$ & 8.86 & 9.24 & 9.05 & 0.00 & 0.02 & 0.11 \\
\hline & 0.38 & ${ }^{137} \mathrm{Cs}$ & 8.48 & 9.67 & 9.07 & & & \\
\hline Dev98 & 0.07 & ${ }^{3} \mathrm{H}$ & 8.18 & 8.32 & 8.25 & -0.34 & -0.19 & -0.79 \\
\hline & 0.12 & ${ }^{137} \mathrm{Cs}$ & 8.00 & 8.12 & 8.06 & & & \\
\hline
\end{tabular}

* Best estimated values. 

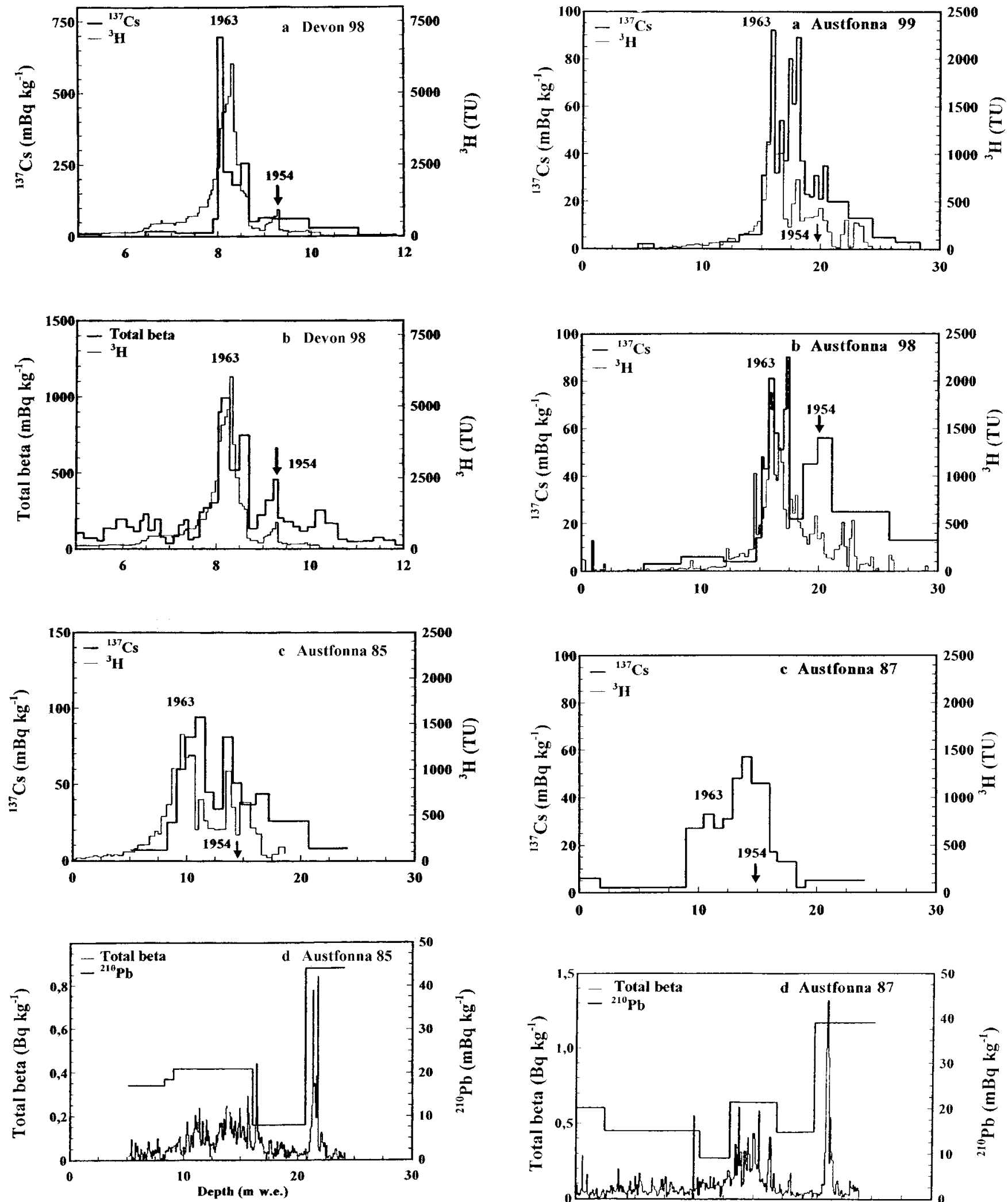

Fig. 3. Radioactivity at time of fall-out $\left({ }^{137} \mathrm{Cs}\right.$ and $\left.{ }^{3} \mathrm{H}\right)$, and at time of measurement (total beta and ${ }^{210} \mathrm{~Pb}$, respectively, 1986 and 1993) vs depth for Devon Ice Cap ( $a, b)$ and Austfonna (c, d). ${ }^{3} \mathrm{H}$ measurements from Devon Island (thin line) are not continuous. The arrow indicates the equivalent 1954 computed year.

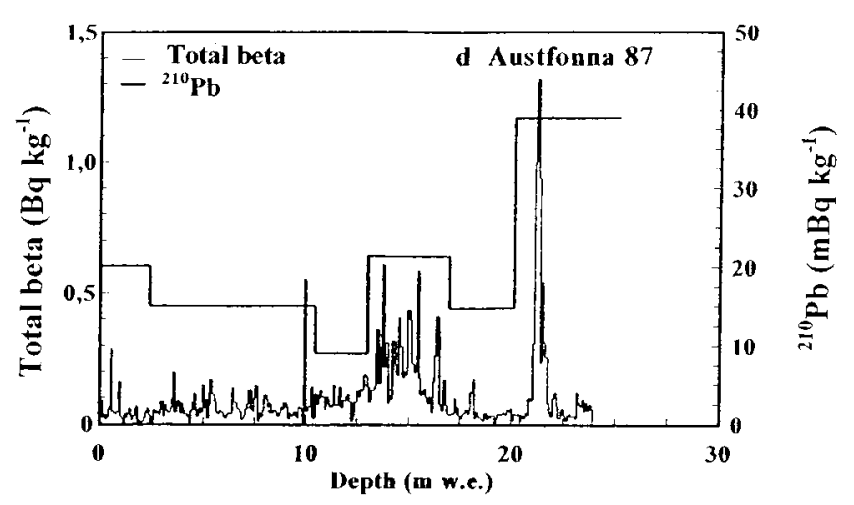

Fig. 4. Radioactivity at time of fall-out $\left({ }^{137} \mathrm{Cs}\right.$ and $\left.{ }^{3} \mathrm{H}\right)$, and at time of measurement (total beta and ${ }^{210} \mathrm{~Pb}$, respectively, 1988 and 1993) vs depth for three ice cores from Austfonna $(a-d)$. The arrow indicates the equivalent 1954 computed year.

a glacier with negative $\left(-23^{\circ} \mathrm{C}\right) 10 \mathrm{~m}$ temperature (Devon Ice Cap) will be compared with profiles from Austfonna, a sub-polar glacier. In cold glaciers the $10 \mathrm{~m}$ temperature is negative, closely representing the mean annual temperature. In the accumulation area of sub-polar glaciers, the 
$10 \mathrm{~m}$ temperature is generally about $0^{\circ} \mathrm{C}$ or slightly negative. It is negative in the ablation area.

For the Devon Ice Cap ice core, there is excellent agreement between total-beta ${ }^{137} \mathrm{Cs}$ and ${ }^{3} \mathrm{H}$ measurements, the 1963 peak of artificial radioactivity occurring at almost the same depth (Fig. 3a and b). The 1963 horizon was generally assigned to depths where there was a clear peak of radioactivity for either ${ }^{3} \mathrm{H}$ or ${ }^{137} \mathrm{Cs}$. For at least two ice cores (Aus87 and Ves81) the identification of the 1963 horizon needs special attention. This 1963 date was fixed in the following way: after the large atmospheric nuclear tests in 1961 and 1962 there was a moratorium, with no other tests for some years. Even if there is not a clear maximum, one can consider that when the radioactivity, after ranging at a given level, falls to a low value at shallower depth, then the 1963 horizon is quite close to this depth.

The ${ }^{3} \mathrm{H}$ profile is not continuous, and extrapolated values were included for estimating the fall-out. Thus the exact location of the 1963 maximum is estimated to occur at depths of 8.18-8.32 m w.e.(Table 2). The ${ }^{137}$ Cs profile also shows the 1959 peak. As will be shown later for other ice cores (Figs 4-6), the beginning of atmospheric fall-out in 1954 is well marked only for the Devon ice core (Koerner and Taniguchi, 1976). The initial increase of ${ }^{137}$ Cs compared to ${ }^{3} \mathrm{H}$ has already been pointed out by Koide and others (1982) and Holdsworth and others (1984).

For the 1985 Austfonna ice core, the radioactivity profiles (Fig. 3c and d) include total beta, ${ }^{137} \mathrm{Cs},{ }^{210} \mathrm{~Pb}$ and ${ }^{3} \mathrm{H}$. For the ${ }^{137} \mathrm{Cs}$ profile, a clear maximum occurs at $9.88-10.76 \mathrm{~m}$ w.e. depth, indicating the 1963 maximum. This is in close agreement with the $1963{ }^{3} \mathrm{H}$ maximum, which is, however, slightly shallower than the ${ }^{137} \mathrm{Cs}$ maximum. The ${ }^{3} \mathrm{H}$ atoms are constituents of the water molecule and, compared to the ${ }^{137} \mathrm{Cs}$ particulates, much of the radioactivity (atoms) contributing to the ${ }^{3} \mathrm{H}$ maximum was not propagated downwards. The ${ }^{137}$ Cs profile shows another maximum at about $13.5 \mathrm{~m}$ w.e., possibly representing the 1959 fall-out (Fig. 3c).

The total-beta profile (Fig. 3d) cannot be used for dating. The clear maximum corresponds to fall-out that occurred well before 1963, as measured from ${ }^{137}$ Cs. It is close to the bottom of the ice core and does not represent any artificial radioactivity. This maximum corresponds to a very high level of ${ }^{210} \mathrm{~Pb}$, as shown on the profile (Fig. 3d). Very similar disturbed total-beta profiles were also measured for Austfonna 1987 (Fig. 4d) and Vestfonna 1981 (Fig. 5c). This ${ }^{210} \mathrm{~Pb}$ increase is not supported by long-lived parents $\left({ }^{238} \mathrm{U}\right.$, ${ }^{226} \mathrm{Ra}$ ). The total-beta values involve beta activity from ${ }^{210} \mathrm{~Pb}$, but also the accompanying alpha and beta activities from the ${ }^{210} \mathrm{~Pb}$ daughters $\left({ }^{210} \mathrm{Bi}\right.$ and $\left.{ }^{210} \mathrm{Po}\right)$ and to a lesser extent from radioactive dust particles $\left({ }^{226} \mathrm{Ra}\right.$ and ${ }^{214} \mathrm{~Pb}$ from ${ }^{238} \mathrm{U}$ parent). Such a large ${ }^{210} \mathrm{~Pb}$ increase also occurs in all ice cores retrieved from Austfonna (1985, 1987 and 1998), except for the 1999 ice core. Although the ${ }^{137} \mathrm{Cs}$ and ${ }^{3} \mathrm{H}$ profiles provide valuable dating information at Austfonna and for ten other ice-core locations (Pinglot and others, 1994), the ${ }^{210} \mathrm{~Pb}$ and total-beta profiles reveal a strong scavenging process due to melting and infiltration for these particulate-composed elements, as for ionic species (Goto-Azuma and others, 1993). Chronologies based on the radioactive decay of a given isotope (e.g. $\left.{ }^{210} \mathrm{~Pb}\right)$ are generally corrupted by post-depositional processes.

Along the ${ }^{137}$ Cs profiles, the 1963 maximum is located at greater depth than in the ${ }^{3} \mathrm{H}$ profiles (Fig. $4 \mathrm{a}$ and b, Table 2). For three ice cores from Austfonna, the 1963 depth differ-
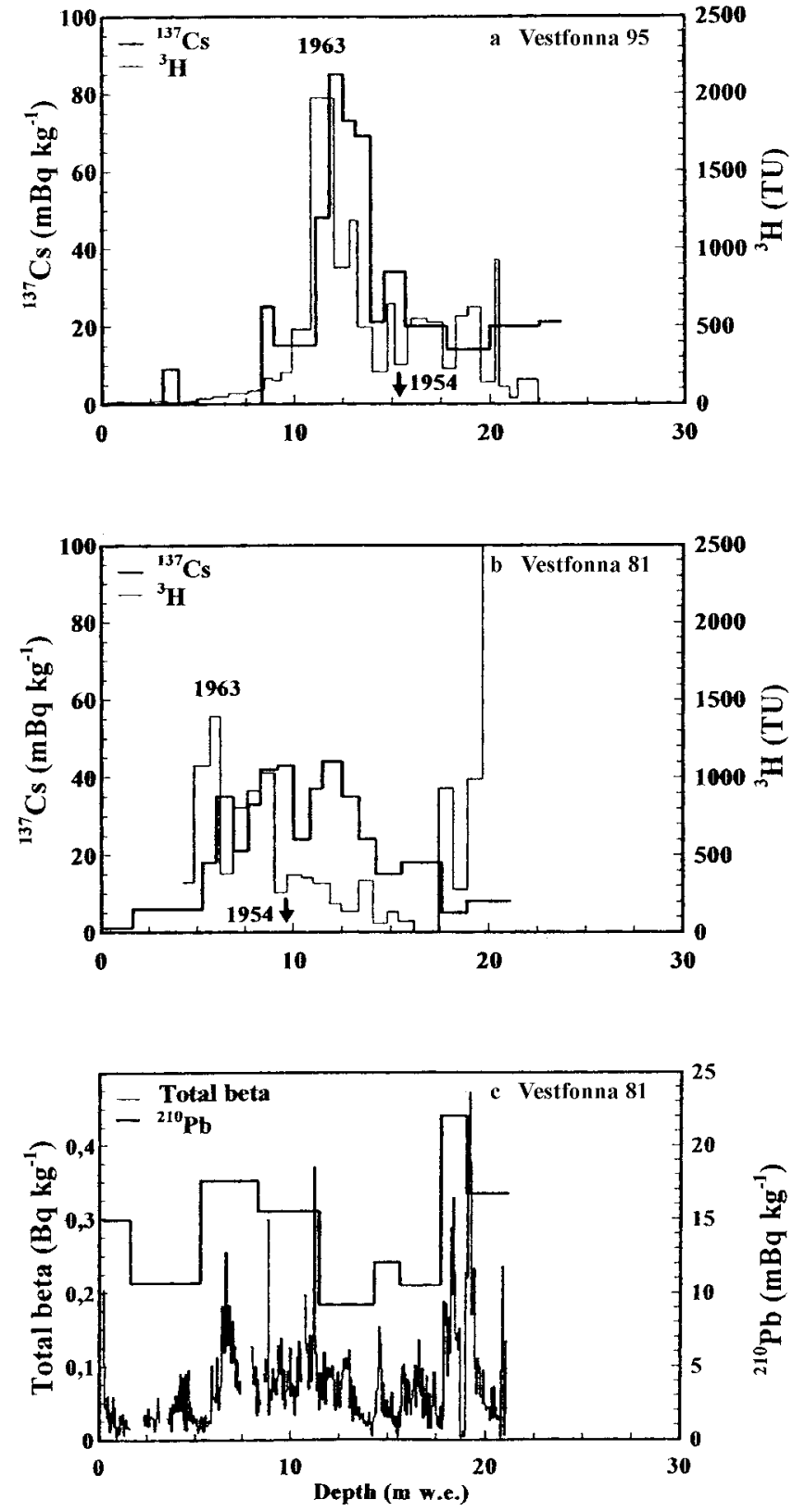

Fig. 5. Radioactivity at time of fall-out ${ }^{137} \mathrm{Cs}$ and $\left.{ }^{3} \mathrm{H}\right)$, and at time of measurement (total beta and ${ }^{210} \mathrm{~Pb}$, respectively, 1982 and 1993) vs depth for three ice cores from Vestfonna $(a-c)$. The arrow indicates the equivalent 1954 computed year.

ence ranges from $0-0.72 \mathrm{~m}$ w.e. corresponding to $0-1.6$ years of net accumulation, while the atmospheric signals indicate that both ${ }^{137} \mathrm{Cs}$ and ${ }^{3} \mathrm{H}$ fall-out peaks occurred at the same time (1963; Fig. 2). This confirms that the ${ }^{137}$ Cs fall-out experiences downward migration due to melting and percolation. Total-beta and ${ }^{210} \mathrm{~Pb}$ profiles at Aus87 (Fig. 4d) and Aus85 (Fig. 3d) are disturbed. This demonstrates that the absolute dating of ice cores in this sub-polar ice cap depends on the isotope measured: the ${ }^{3} \mathrm{H}$ profile gives a better chronology than ${ }^{137}$ Cs.

\section{Vestfonna}

Samples from two ice cores from Vestfonna were also analyzed for ${ }^{137}$ Cs and ${ }^{3} \mathrm{H}$ (Fig. $5 \mathrm{a}$ and b).

For the 1981 Vestfonna ice core (Fig. 5b), there is a clear deformation of the original atmospheric signal both for ${ }^{137} \mathrm{Cs}$ and ${ }^{3} \mathrm{H}$. The tentative depth given for the 1963 peak is 

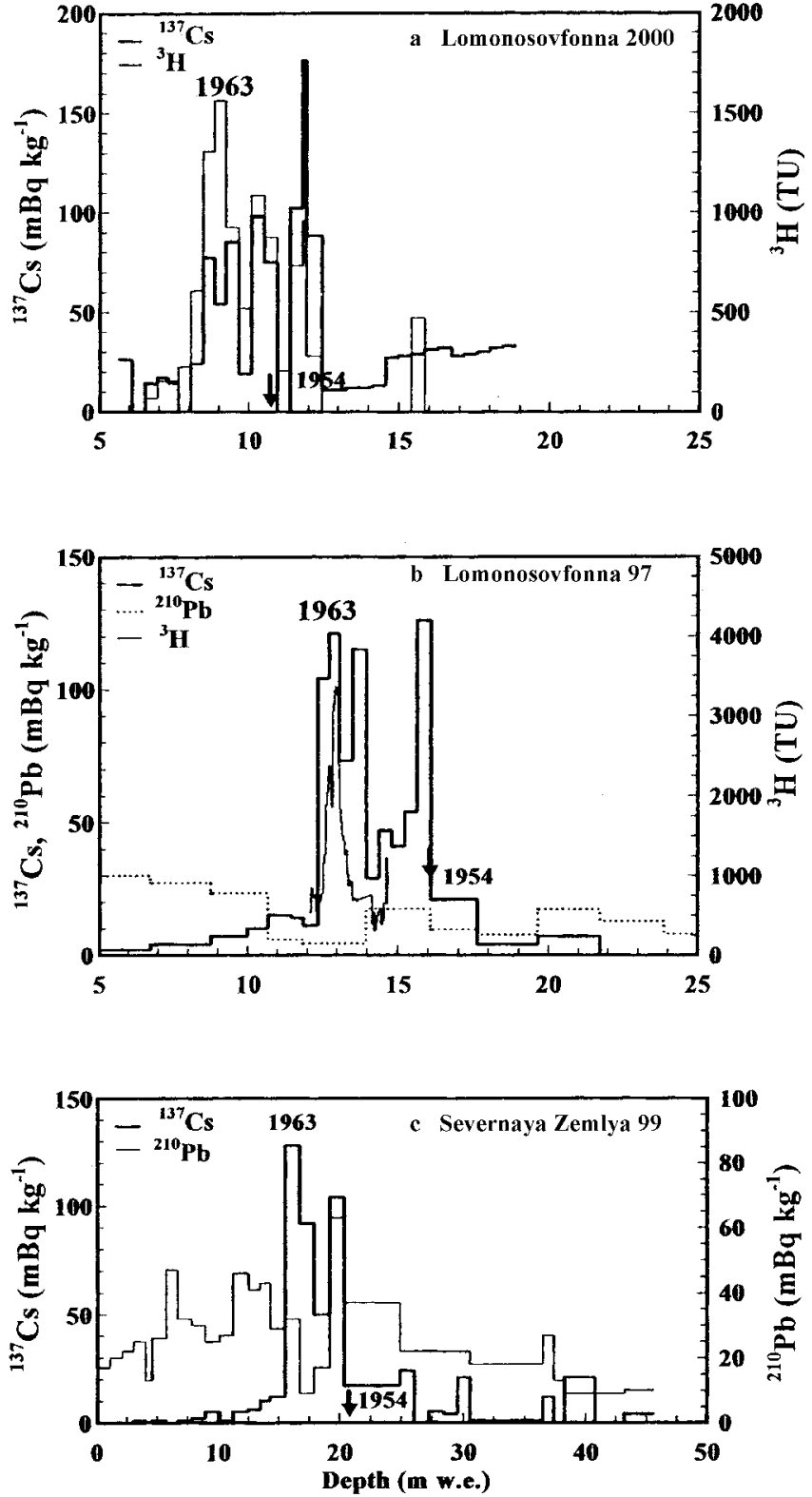

Fig. 6. Radioactivity at time of fall-out $\left({ }^{137} \mathrm{Cs}\right.$ and $\left.{ }^{3} \mathrm{H}\right)$, and at time of measurement (total beta and ${ }^{210} \mathrm{~Pb}$, respectively, 1998 and 2000) vs depth for two ice cores from Lomonosovfonna ( $a$, b) and for an ice core from Akademii Nauk ice cap (c). The arrow indicates the equivalent 1954 computed year.

based on the ${ }^{3} \mathrm{H}$ profile as the ${ }^{137} \mathrm{Cs}$ profile shows a strongly disturbed signal. The depth difference ranges from $0.60-$ $0.73 \mathrm{~m}$ w.e. and corresponds to about 1.7 and 1.9 years of net accumulation for Vestfonna 1981 and 1995, respectively (Table 2). Note that the summit of Vestfonna (580$600 \mathrm{~m}$ a.s.l.) is lower than Austfonna (758-783 m a.s.l.), so higher melting is more likely at Vestfonna.

\section{Lomonosovfonna}

The same analyses were conducted for two ice cores from Lomonosovfonna, drilled in 1997 (Lom97) and 2000 (Lom00) (Table 1), located about $150 \mathrm{~m}$ from each other (Fig. $6 \mathrm{a}$ and b). For the 1997 core, there are similar trends for ${ }^{137} \mathrm{Cs}$ and ${ }^{3} \mathrm{H}$ and the 1963 peak is well-defined. The detailed ${ }^{3} \mathrm{H}$ profile (preliminary, as all samples are not yet analyzed) was determined from the analysis of $5 \mathrm{~cm}$ resolution samples.

For the core drilled in 2000 , the ${ }^{3} \mathrm{H}$ profile reflects the

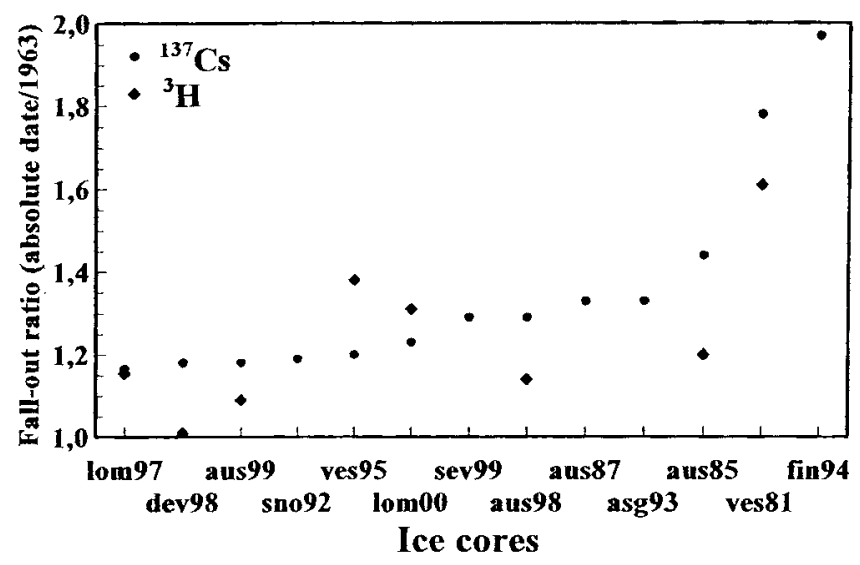

Fig. 7. ${ }^{137} \mathrm{Cs}$ and ${ }^{3} \mathrm{H}$ fall-out ratio from atmospheric nuclear tests, determined from 1963 mean time of fall-out and absolute date of snow layers, respectively.

atmospheric signal while the ${ }^{137} \mathrm{Cs}$ profile shows large temporal variations. The 1963 layer at Lom00 (9.05 m w.e.) is not as deep as the Lom97 ice core (12.98 m w.e.) (Table 2). As discussed below, the low ${ }^{3} \mathrm{H}$ fall-out at Lom00 most probably indicates that the original precipitation is low, as is the MANMB. The ${ }^{210} \mathrm{~Pb}$ profile (Fig. $6 \mathrm{~b}$ ) at Lom97 indicates a general decrease of activity with depth. However, dating of this ice core from ${ }^{210} \mathrm{~Pb}$ decay does not reproduce the 1963 horizon.

\section{Akademii Nauk ice cap}

In order to extend our study of the spatio-temporal variations of the MANMB and the global mass budget to other glaciers and ice caps in the high Arctic, ${ }^{137} \mathrm{Cs}$ and ${ }^{210} \mathrm{~Pb}$ profiles were also measured in an ice core from Akademii Nauk ice cap (Fig. 6c). The 1963 peak for ${ }^{137}$ Cs is well-defined between 15.55 and $16.73 \mathrm{~m}$ w.e. This is in agreement with the 1956 Bezymianni volcanic layer studied by Fritzsche and others (2002). Previously, Vaikmäe and others (1980) analyzed ${ }^{3} \mathrm{H}$ at the nearby Vavilov ice cap and concluded that the corresponding profile was disturbed. The 1954 computed year of ${ }^{137} \mathrm{Cs}$ fall-out does not correspond to this absolute date. Therefore it could be concluded that melting also occurs at the summit of Akademii Nauk ice cap, which is supported by positive air temperatures recorded by an automatic weather station here in summer 2000 (Hagen and Melvold, 2001). Vaikmäe and others (1981) even reported temperature of $+10-15^{\circ} \mathrm{C}$ at Severnaya Zemlya.

\section{INTERPRETATION AND DISGUSSION}

\section{Chronology}

The ice cores from the Arctic area have been dated using radioactivity measurements. The most accurate detection of the 1963 peak of artificial radioactivity is obtained from ${ }^{3} \mathrm{H}$ using the proportional-counting technique, and then from ${ }^{137}$ Cs. This is due to the higher resolution of samples subjected to ${ }^{3} \mathrm{H}$ analysis, 0.04 and $0.07 \mathrm{~m}$ w.e. for the Lom97 and Dev98 ice cores, respectively (Table 2). Gamma spectrometry of ${ }^{137} \mathrm{Cs}$ needs samples with higher mass and length, compared to ${ }^{3} \mathrm{H}$ analysis. ${ }^{3} \mathrm{H}$ dates are also better than ${ }^{137} \mathrm{Cs}$ because the 1963 horizons are much stronger for ${ }^{3} \mathrm{H}$ and largely remain at the original fall-out depth. There 
Table 3. ${ }^{137}$ Cs and ${ }^{3} H$ for 13 ice cores: MANMB from 1963 to date of drilling; fall-out from atmospheric nuclear tests (corrected for 1963 mean fall-out date and the absolute date of each snow layer); and fall-out ratio (fall-out at absolute date vs fall-out in 1963)

\begin{tabular}{|c|c|c|c|c|c|c|c|c|}
\hline \multirow[t]{3}{*}{ Ice cores } & \multicolumn{4}{|c|}{${ }^{137} \mathrm{Cs}$} & \multicolumn{4}{|c|}{${ }^{3} H$} \\
\hline & $M A \mathcal{N} M B$ & Depth 1963 & Depth abs. & Ratio (1963/abs.) & $M A \mathcal{N M B}$ & Depth 1963 & Depth abs. & Ratio (1963/abs.) \\
\hline & m w.e. & $\mathrm{Bq} \mathrm{m} \mathrm{m}^{-2}$ & $\mathrm{~Bq} \mathrm{~m}^{-2}$ & & mw.e. & $\mathrm{TUm}$ & TUm & \\
\hline Ves81 & 0.35 & 224 & 398 & 1.78 & 0.33 & 4595 & 7381 & 1.61 \\
\hline Ves95 & 0.38 & 369 & 444 & 1.20 & 0.36 & 5688 & 7842 & 1.38 \\
\hline Aus85 & 0.47 & 434 & 626 & 1.44 & 0.44 & 6505 & 7825 & 1.20 \\
\hline Aus87 & 0.45 & 269 & 357 & 1.33 & n.d. & n.d. & n.d. & n.d. \\
\hline Aus98 & 0.46 & 407 & 526 & 1.29 & 0.45 & 5440 & 6200 & 1.14 \\
\hline Aus99 & 0.44 & 293 & 346 & 1.18 & 0.44 & 4319 & 4718 & 1.09 \\
\hline Sno92 & 0.47 & 259 & 308 & 1.19 & 0.47 & n.d. & n.d. & n.d. \\
\hline Asg93 & 0.31 & 418 & 555 & 1.33 & 0.31 & n.d. & n.d. & n.d. \\
\hline Fin94 & 0.17 & 461 & 907 & 1.97 & n.d. & n.d. & n.d. & n.d. \\
\hline Lom97 & 0.36 & 343 & 398 & 1.16 & 0.36 & 3709 & 4301 & 1.16 \\
\hline Lom00 & 0.23 & 279 & 342 & 1.23 & 0.23 & 2979 & 3893 & 1.31 \\
\hline Sev99 & 0.45 & 549 & 709 & 1.29 & n.d. & n.d. & n.d. & n.d. \\
\hline Dev98 & 0.23 & 310 & 365 & 1.18 & 0.24 & 4862 & 4158 & 0.86 \\
\hline
\end{tabular}

Note: n.d., not determined.

is generally a stronger migration of ${ }^{137} \mathrm{Cs}$ compared to ${ }^{3} \mathrm{H}$, as shown below (Fig. 7). The depth differences for the 1963 peak, based on ${ }^{137} \mathrm{Cs}$ and ${ }^{3} \mathrm{H}$, are indicated in Table 2, together with the corresponding age differences. Minimum and maximum depths correspond to the length of samples representing the 1963 layer. While this layer is well defined for ${ }^{3} \mathrm{H}$, the ${ }^{137} \mathrm{Cs}$ layer corresponding to 1963 was in some cases estimated to be just before the decrease of activity following the nuclear-test moratorium. However, for each ice core, the depth differences for 1963 is lower than the length of the corresponding ${ }^{3} \mathrm{H}$ or ${ }^{137} \mathrm{Cs}$ sample (Table 2).

The differences in dating obtained using ${ }^{137} \mathrm{Cs}$ and ${ }^{3} \mathrm{H}$ are close to zero for several ice cores and may be not significant for the other ice cores.The maximum difference may extend up to 2 years at Vestfonna and slightly opposite $(-0.8$ year $)$ for Devon Ice Cap. This may be due to the discontinuous ${ }^{3} \mathrm{H}$ sampling, with one sample in the 1963 layer that was not analyzed. The total-beta activity profile was used to estimate the probable depth of the 1963 layer for ${ }^{3} \mathrm{H}$ (i.e. $8.18-8.32 \mathrm{~m}$ w.e.).

\section{Mean annual net mass balances (MANMB)}

All ice cores were retrieved from the summits of the studied ice caps with very low horizontal velocities and terrain slopes. The thinning effect of deeper ice layers (down to $40 \mathrm{~m}$ in this study) is negligible, and we can use the chronology results to determine the MANMB.

The MANMB values range from 0.17 (Fin94) to 0.47 m w.e. $\mathrm{a}^{-1}$ (Aus85 and Sno92) (Table 3) from 1963 to the drilling dates (1981-2000). Apart from a MANMB value determined for Devon Ice Cap by Koerner and Taniguchi (1976), earlier MANMB values determined for other Arctic locations do not agree with our determinations, due to difficulties in interpreting the stratigraphy and total-beta profiles. This is particularly true for ice cores from Nordaustlandet (Vestfonna and Austfonna), where MANMBs were previously misinterpreted, as shown by Pinglot and others, 2001.

The MANMBs of Lom97 and Lom00 ice cores (1250 $\mathrm{m}$ a.s.l.) are 0.36 and $0.23 \mathrm{~m}$ w.e. $\mathrm{a}^{-1}$, respectively. These are much lower than the previous $0.82 \mathrm{~m}$ w.e. $\mathrm{a}^{-1}$ value determined for a $1000 \mathrm{~m}$ a.s.l. site (Gordiyenko and others, 1981).
Earlier studies (Zagorodnov and others, 1990) reported MANMB values at the summit of Akademii Nauk ice cap ranging from $0.20-0.30 \mathrm{~m}$ w.e. $\mathrm{a}^{-1}$ compared to our determination of $0.45 \mathrm{~m}$ w.e. $\mathrm{a}^{-1}$.

\section{${ }^{137} \mathrm{Cs}$ and ${ }^{3} \mathrm{H}$ fall-out and melt indexes}

Both ${ }^{137} \mathrm{Cs}$ and ${ }^{3} \mathrm{H}$ fall-out from atmospheric nuclear tests (1954-74) over Arctic glaciers have been determined (Table 3). The transport mechanisms (residence time) of ${ }^{3} \mathrm{H}$ and ${ }^{137}$ Cs through the atmosphere are almost the same (Pourchet and Pinglot, 1979), so they do not affect the location of the 1963 peak in the cores. Assuming a constant MANMB at each ice-core location, as already demonstrated for the period from 1963 to the date of the drillings (Pinglot and others, 1999), the ${ }^{137} \mathrm{Cs}$ and ${ }^{3} \mathrm{H}$ activity profiles have been decay-corrected, taking into account the precise date of the snow layers. This will enable us to compute the fall-out of both isotopes in two ways. The hypothesis is that the exact 1963 peak did not propagate downward. Even if 1963 is not the exact mean date of atmospheric nuclear tests fall-out, the melt index studied is representative of the strength of melting and percolation processes.

In the first correction for decay, we assume that the mean date of fall-out for all samples is 1963. This is a reasonable assumption, given that the total period of atmospheric nuclear testing extends equally before and after 1963. For the second correction, each sample radioactivity value is corrected to take into account the absolute date of the snow layers. From the date of drilling, dating is given by the equivalent depth ( $\mathrm{m}$ w.e.) divided by the MANMB, as previously determined. Both corrections take into account the date of all measurements, extending from 1983-2000 (Table 3). The depth of the layer corresponding to the year 1954 (first significant increase of artificial radioactivity in the Arctic) was then determined and included on all profiles (Figs 3-6).

There is a general disagreement between the 1954 computed equivalent depth and the first increase of isotopes. The ${ }^{137}$ Cs profiles apparently propagated to greater depths than the 1954 equivalent depth. This clearly demonstrates the post-depositional processes due to melting and percolation during successive summers. Periods of melting during 

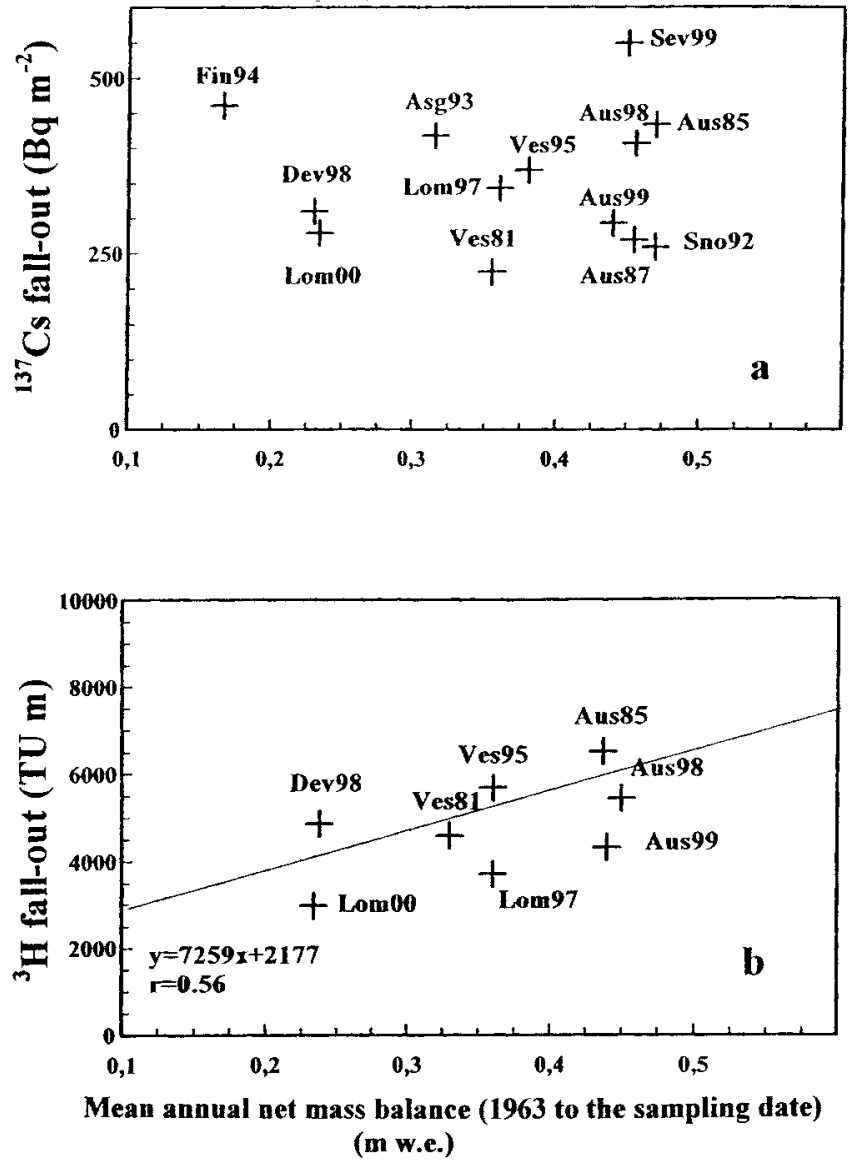

Fig. $8 .{ }^{137} \mathrm{Cs}$ ( a) and ${ }^{3} \mathrm{H}(\mathrm{b})$ fall-out from atmospheric nuclear tests vs MANMB for 13 high-Arctic ice cores.

warmer summers in the early 1950s have been reported (Fisher and Koerner, 1994; Førland and others, 1997). This is also in accordance with the ${ }^{210} \mathrm{~Pb}$ profile (Fig. $3 \mathrm{~d}$ ), showing a major activity peak at greater depths, as has been detected for other Austfonna ice cores (Pinglot and others, 1994). ${ }^{137}$ Cs and ${ }^{3} \mathrm{H}$ fall-out will be overestimated as a result of the overestimation of the age of deeper samples. Figure 7 indicates both the ${ }^{137} \mathrm{Cs}$ and ${ }^{3} \mathrm{H}$ fall-out ratio, as determined either from a decay correction of fall-out computed for 1963 or for the absolute date of each snow layer.

This fall-out ratio represents a melt-index equivalent. Instead of a fall-out ratio ideally equal to 1 for cold glaciers and ice caps, the present fall-out ratios are close to 1.2 for ice cores from Lomonosovfonna (Lom97), Devon Ice Cap (Dev98) and Snøfjella (Sno92) (Table 3). For the other cores studied, the respective fall-out ratio increases, ranging up to about 2 for lower-altitude cores from Vestfonna (Ves81) and Finsterwalderbreen (Fin94), at 580 and $668 \mathrm{~m}$ a.s.l., respectively.

The fall-out ratio is generally higher for ${ }^{137} \mathrm{Cs}$ than for ${ }^{3} \mathrm{H}$ (five cores), except for Ves95 and Lom00. This melt-index study also demonstrates that percolation is less important for ${ }^{3} \mathrm{H}$ than ${ }^{137}$ Cs. As the ${ }^{137}$ Cs profile at Lom00 core reveals large variations, perhaps the corresponding corrected fallouts were not determined accurately. This demonstrates that for a given ice-core location, the study of the fall-out of radioactivity can be used to determine the relative strength of the melting and percolation processes. There is evidence that cores from cold glaciers are less subjected to these processes. However, all cores from sub-polar glaciers experience large post-depositional processes, as described by Koerner (1997) and Tarussov (1992).

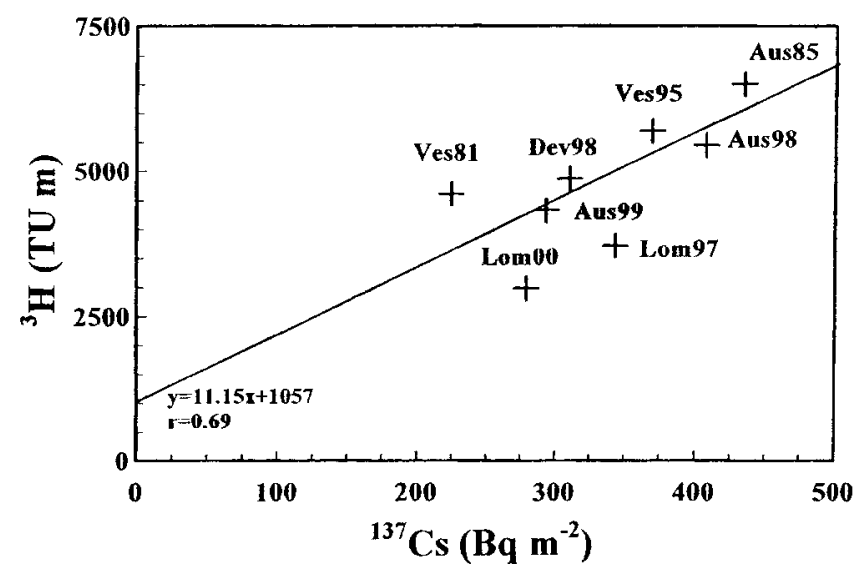

Fig. 9. ${ }^{3} \mathrm{H}$ vs ${ }^{137}$ Cs fall-out from atmospheric nuclear tests at eight Arctic ice-core locations.

The best estimates for ${ }^{137} \mathrm{Cs}$ and ${ }^{3} \mathrm{H}$ fall-out are determined from the 1963 decay-corrected values, as the decay correction of fall-out, applied for each snow-layer date, leads to overestimated values. As already specified, MANMB at each ice-core location is almost constant for periods extending from 1963-86 and from 1986 to the drilling dates (Pinglot and others, 1999). From this important feature for ice cores from Svalbard, ${ }^{137} \mathrm{Cs}$ and ${ }^{3} \mathrm{H}$ fall-out is studied in relation to the MANMB for each core location (Fig. 7a and b), even if the all periods are not the same.

${ }^{137} \mathrm{C}$ s fall-out from the nuclear tests for all studied cores spans from 224 (Ves81) to $549 \mathrm{~Bq} \mathrm{~m}^{-2}$ (Sev99) (Fig. 8a). Altogether, the mean ${ }^{137}$ Cs fall-out values for the 13 Arctic and 11 Svalbard ice cores are $355 \mathrm{~Bq} \mathrm{~m}^{-2}\left( \pm 95 \mathrm{~Bq} \mathrm{~m}^{-2}\right)$ and $341 \mathrm{~Bq} \mathrm{~m}^{-2}\left( \pm 81 \mathrm{~Bq} \mathrm{~m}^{-2}\right)$, respectively. For four ice cores near the summit of Austfonna, the fall-out values extend from $269-434 \mathrm{~Bq} \mathrm{~m}^{-2}$. Fall-out values are 310 and $549 \mathrm{~Bq} \mathrm{~m}^{-2}$, respectively, for the Devon Ice Cap and Akademii Nauk ice cap cores (Table 3). The fall-out apparently tends to decrease from eastern to more western Arctic locations. This agrees with the ${ }^{137}$ Cs fall-out in the Arctic predicted by Wright and others (1999) using a geographical information system to combine ${ }^{137} \mathrm{Cs}$ fall-out and precipitation data.

The mean ${ }^{3} \mathrm{H}$ fall-out for the same $1954-74$ period is $4762 \pm 1126$ TUm for eight ice cores and spans from 29796505 TUm (Fig. 8b). For comparison, the ${ }^{3} \mathrm{H}$ fall-out measured for the Isfjord Radio coastal station in Svalbard (IAEA, 1984) for the period $1961-76$ is 2793 TUm. This is in accordance with the ${ }^{3} \mathrm{H}$ data from ice cores, as the ${ }^{3} \mathrm{H}$ fall-out at Isfjord Radio (mean annual precipitation is $0.444 \mathrm{~m}$ ) was not recorded before 1961. The ${ }^{3} \mathrm{H}$ fall-out increases with MANMB $(r=0.56)$, from a previous study in Greenland (Merlivat and others, 1973). A null ${ }^{137}$ Cs fall-out corresponds to about a $1000 \mathrm{TUm}{ }^{3} \mathrm{H}$ fall-out (Fig. 8b). This corresponds to the natural ${ }^{3} \mathrm{H}$ fall-out $\left(\sim 50 \mathrm{TU} \mathrm{ma}^{-1}\right)$ over 20 years, the period when artificial ${ }^{3} \mathrm{H}$ was also deposited (1954-74).

For all ice cores, there should be proportionality between ${ }^{137} \mathrm{Cs}$ and ${ }^{3} \mathrm{H}$ fall-out from atmospheric nuclear tests. This relationship prevails and exhibits a 0.69 correlation coefficient (Fig. 9). The ${ }^{3} \mathrm{H}$ fall-out at Lomonosovfonna (Lom97 and Lom00), 3709 (estimated value, as some samples were not analyzed) and $2979 \mathrm{TU}$ m, respectively, is low compared to the other ice cores (mean of $4913 \mathrm{TUm}$ ) (Fig. 8b).

${ }^{137} \mathrm{Cs}$ fall-out in the Lom97 and Lom00 ice cores, 343 and $279 \mathrm{~Bq} \mathrm{~m}^{-2}$, respectively, is close to the mean value of 
Svalbard ice cores $\left(341 \mathrm{~Bq} \mathrm{~m}^{-2}\right)$, indicating that wind erosion may be low, but cannot explain the surprisingly low MANMB at the Lomonosovfonna sites at the summit of this ice cap. Analysis of three ice cores from the Lomonosovfonna dome did not show the presence of the Chernobyl signal, indicating that some wind scouring occurs at this location. However, the Chernobyl event was present in ice cores located at lower altitudes (1044 and $1173 \mathrm{~m}$ a.s.l.). A close examination at the relationship between ${ }^{137} \mathrm{Cs}$ and ${ }^{3} \mathrm{H}$ fallout (Fig. 9) reveals that both the Lom97 and Lom00 ice cores experience about $25 \%$ lower ${ }^{3} \mathrm{H}$ fall-out than the mean values. This may be due to snow and ${ }^{3} \mathrm{H}$ sublimation, as described by Winther and others (1998).

\section{The 1986 Chernobyl layer}

${ }^{137}$ Cs fall-out from the Chernobyl accident has been successfully detected in about 50 Svalbard ice cores (Lefauconnier and others, 1994; Pourchet and others, 1996; Pinglot and others, 1994, 1997, 1999, 2001). More recently, we determined the Chernobyl fall-out for the Devon and Akademii Nauk ice caps. The ${ }^{137} \mathrm{Cs}$ fall-out varies from $0-47 \mathrm{~Bq} \mathrm{~m}^{-2}$ for the Svalbard ice cores. Wind scouring has been determined to be the main factor explaining this variability, as the fall-out from Chernobyl only occurred during a few days (Pinglot and others, 2001). The fall-out on Devon Island is $5 \mathrm{~Bq} \mathrm{~m}^{-2}$ for two ice cores. This value is of the same order as the Svalbard and Greenland values (Dibb, 1989). On Severnaya Zemlya, the ${ }^{137} \mathrm{Cs}$ fall-out is about $1 \mathrm{~Bq} \mathrm{~m}^{-2}$, as determined from a shallow ice core retrieved in 2000. This low value is close to the detection limit of our low-level gamma spectrometer. It would appear however to be valid, given that the corresponding mass balance for $1986-2000$ is $0.52 \mathrm{~m}$ w.e. compared to $0.45 \mathrm{~m}$ w.e. for $1963-2000$ (Table 3).

\section{Dating from ${ }^{210} \mathrm{~Pb}$ profiles}

Both ${ }^{137}$ Cs and ${ }^{210} \mathrm{~Pb}$ were simultaneously analyzed by gamma spectrometry. The ${ }^{210} \mathrm{~Pb}$ profiles for Aus85, Aus87 and Ves81 ice cores (Figs 3d, 4d and 5c) indicate a strong ${ }^{210} \mathrm{~Pb}$ increase between 18 and $24 \mathrm{~m}$ w.e. Samples from other ice cores from Austfonna, Vestfonna and Spitsbergen were also analyzed for ${ }^{210} \mathrm{~Pb}$. The corresponding ${ }^{210} \mathrm{~Pb}$ profiles are included in Pinglot and others (1994). Other ice cores from Svalbard (Asg93 and Sno92) have also been analyzed for ${ }^{210} \mathrm{~Pb}$ (Suzuki and Fujii, 1992; Suzuki and others, 1995). There is no exponential decay starting from the surface down, for any profile. The ${ }^{210} \mathrm{~Pb}$ profile (Fig. 6b) for Lom97 indicates a general decrease of activity with depth. However, the dating of this ice core, based on ${ }^{210} \mathrm{~Pb}$ decay, does not correctly position the 1963 radioactive layer from atmospheric nuclear tests.

For Akademii Nauk ice cap, a formerly determined ${ }^{210} \mathrm{~Pb}$ profile (Zagorodnov and others, 1990) can be closely compared to the new profile (Fig. 6c). Instead of a regular decrease of the ${ }^{210} \mathrm{~Pb}$ activity with depth, the activity is almost stable (and even increases with depth in the first $10 \mathrm{~m}$ ) from the surface down to about $25 \mathrm{~m}$ w.e. Then the activity regularly decreases, as expected. This unusual feature was already reported by Zagorodnov and others (1990). At a depth of about $20 \mathrm{~m}$ w.e., there is even a high level of ${ }^{210} \mathrm{~Pb}$ activity. The interpretation may be that ${ }^{210} \mathrm{~Pb}$ particulates travel downward into the deeper firn layers due to summer melting and percolation. Once the firn layers reach a density close to 0.9, the migration of ${ }^{210} \mathrm{~Pb}$ stops and its activity begins to decrease, as seen below $30 \mathrm{~m}$ depth. This indicates that dating based on the ${ }^{210} \mathrm{~Pb}$ half-life (22 years) may be impossible for most ice cores from sub-polar glaciers.

\section{GONGLUSIONS}

Dating of Arctic ice cores based on the 1963 maximum of artificial radioactivity originating from atmospheric nuclear tests was initially performed using the total-beta technique. This sensitive (and relatively inexpensive) method is valid for ice cores retrieved from cold glaciers, such as those in high-Arctic Canada, central Greenland and Antarctica. For ice cores retrieved from sub-polar glaciers that experience melting and percolation in summer, the best dating is accomplished using ${ }^{3} \mathrm{H}$ and ${ }^{137} \mathrm{Cs}$. The original fall-out depth of the 1963 maximum is better preserved for the ${ }^{3} \mathrm{H}$ profiles for most ice cores. Arctic ice cores have been successfully dated from both atmospheric nuclear tests and the Chernobyl accident based on ${ }^{137}$ Cs measurements in Svalbard, high-Arctic Canada (Devon Island) and Severnaya Zemlya. The ${ }^{137}$ Cs and ${ }^{3} \mathrm{H}$ activity profiles have been decay-corrected either for the mean 1963 fall-out date or for the precise dates of the snow layers. A fall-out ratio, or melt index, has been derived from both fall-out values and represents the extent of melting and percolation for all 13 ice cores studied.

For several locations, the ${ }^{210} \mathrm{~Pb}$ profiles indicate a clear mixing of seasonal layers for certain chemical elements. Radioactivity measurements confirm that the seasonal signal may not be preserved in sub-polar Arctic glaciers. On the other hand, the Lomonosovfonna $1997{ }^{3} \mathrm{H}$ profile with high spatial resolution indicates the conservation of sub-annual signals to at least some extent. Continuation of the analysis of the 1970's samples will reveal how far the semi-annual ${ }^{3} \mathrm{H}$ precipitation signal is conserved in this core. The dating method based on the ${ }^{210} \mathrm{~Pb}$ exponential decrease with depth (expressed in water equivalent) is possibly valid for selected high-altitude sites in Svalbard.

These radioactivity measurements provide access to key parameters for the study of Arctic glaciers. The absolute chronology of ice cores is the most important feature. In relation to possible climate warming and sea-level rise, the MANMB with the associated spatio-temporal variations (1963-86 and 1986 to the date of drilling) can be studied using radioactive horizons. The total mass budget of the accumulation area of the studied glaciers is determined from the altitudinal gradient of the MANMB, which is also incorporated in mass-balance models. Radioactivity measurements also provide a better understanding of post-depositional processes, such as melting and percolation as well as wind scouring, which affect the distribution of both natural and artificial isotopes.

\section{ACKNOWLEDGEMENTS}

This study was funded by several EU contracts, including contract No. ENV04-CT97-0490: "The response of Arctic ice masses to climate change" (ICEMASS), coordinated by J. O. Hagen. Comments and advice from all colleagues of the International Arctic Science Committee-Mass balance of Arctic Glaciers and Ice sheets in relation to the Climate and Sea-level changes (IASC-MAGICS) group were very fruitful. Logistical and financial support respectively from the Norwegian Polar Institute and Institut Français de la Recherche et de la Technologie Polaires was greatly appreciated. $\mathrm{H}$. 
Miller and L. M. Savatyugin initiated close cooperation with the Severnaya Zemlya programme. I. Glark, D. A. Fisher, K. Goto-Azuma and J. Chappelaz participated in Devon Island ice-core recovery, stratigraphy and sample management. We would also like to thank the ice-core drillers, including $\mathrm{V}$. Zagorodnov and M. Miyahara. C. Pinglot, M. Kaczmarska and B. Lefauconnier took part in the chemical preparation of samples. Comments from two anonymous reviewers and from D. A. Peel and W. D. Harrison, respectively Scientific and Chief Editor, were greatly appreciated and improved this paper in many ways.

\section{REFERENGES}

Aarkrog, A., Y. Tsaturov and G.G. Polikarpov. 1994. Sources of environmental radioactive contamination in the former U.S.S.R. Luxembourg, European Commission. (Radiation Protection 71.)

Delmas, R. and M. Pourchet. 1977. Utilisation de filtres échangeurs d'ions pour l'étude de l'activité $\beta$ globale d'un carottage glaciologique. International Association of Hydrological Sciences Publication 118 (Symposium at Grenoble 1975 - Isotopes and Impurities in Snow and Ice), 159-163.

Dibb, J. 1989. The Chernobyl reference horizon (?) in the Greenland ice sheet. Geophys. Res. Lett., 16(9), 987-990.

Fisher, D. A. and R. M. Koerner. 1994. Signal and noise in four ice-core records from the Agassiz Ice Cap, Ellesmere Island, Canada: details of the last millennium for stable isotopes, melt and solid conductivity. Holocene, 4(2), 113-120.

Førland, E. J., I. Hanssen-Bauer and P. Ø. Nordli. 1997. Climate statistics and longterm series of temperatures and precipitation at Svalbard and Jan Mayen. Oslo, Det Norske Meteorologiske Institutt. (DNMI Klima Report 21/97.)

Fritzsche, D. and 6 others. 2002. A new deep ice core from Akademii Nauk ice cap, Severnaya Zemlya, Eurasian Arctic: first results. Ann. Glaciol., 35, 25-28.

Gordiyenko, F. G., V. M. Kotlyakov, Ya.-M. K. Punning and R. A. Vaikmäe. 1981. Study of a 200-m core from the Lomonosov ice plateau on Spitsbergen and the paleoclimatic implications. Polar Geogr. Geol., 5 (4), 242-251.

Goto-Azuma, K., H. Enomoto, S. Takahashi, S. Kobayashi, T. Kameda and O. Watanabe. 1993. Leaching of ions from the surface of glaciers in western Svalbard. Bull. Glacier Res. 11, 39-50.

Goto-Azuma, K. and 6 others. 1995. An ice-core chemistry record from Snøfjellafonna, northwestern Spitsbergen. Ann. Glaciol., 21, 213-218.

Hagen, J. O. and K. Melvold. 2001. The response of Arctic Ice Masses to Climate Change (Icemass). Oslo, University of Oslo. Department of Physical Geography. (Third year report, E.C. contract ENV04-CT97-0490)

Holdsworth, G., M. Pourchet, F. A. Prantl and D. P. Meyerhof. 1984. Radioactivity levels in a firn core from the Yukon Territory, Canada. Atmos. Environ., 18(2), 461-466.

International Atomic Energy Agency (IAEA). 1984. Statistical treatment of environmental isotope data in precipitation. Vienna, International Atomic Energy Agency. (IAEA Technical Report Series 206.)

Isaksson, E. and 14 others. 2001. A new ice-core record from Lomonosovfonna, Svalbard: viewing the 1920-97 data in relation to present climate and environmental conditions. F. Glaciol., 47(157), 335-345

Koerner, R. M. 1997. Some comments on climatic reconstructions from ice cores drilled in areas of high melt. F. Glaciol., 43(143), 90-97. (Erratum: 43(144), p. 375-376)

Koerner, R. M. and H. Taniguchi. 1976. Artificial radioactivity layers in the Devon Island ice cap, Northwest Territories. Can. F. Earth Sci., 13(9), $1251-1255$.

Koide, M., R. Michel, E. D. Goldberg, M. M. Herron and C. C. Langway, Jr. 1982. Characterization of radioactive fallout from pre- and postmoratorium tests to polar ice caps. Nature, 296(5857), 544-547.

Kotzer, T. G., A. Kudo, J. Zheng and W. Workman. 2000. Natural and anthropogenic levels of tritium in a Canadian Arctic ice core, Agassiz Ice Cap, Ellesmere Island, and comparison with other radionuclides. $\mathcal{F}$. Glaciol., 46(152), 35-40.

Lefauconnier, B., J. O. Hagen, J. F. Pinglot and M. Pourchet. 1994. Massbalance estimates on the glacier complex Kongsvegen and Sveabreen, Spitsbergen, Svalbard, using radioactive layers. F. Glaciol., 40(135), 368-376.

Merlivat, L., J. Ravoire, J. P. Vergnaud and C. Lorius. 1973. Tritium and deuterium content of the snow in Greenland. Earth Planet. Sci. Lett., $19(2), 235-240$
Pinglot, J. F. and M. Pourchet. 1979. Low-level beta counting with an automatic sample changer. Nucl. Instrum. Methods, 166, 483-490.

Pinglot, J. F. and M. Pourchet. 1994. Spectrométrie gamma à très bas niveau avec anti-Compton $\mathrm{NaI}(\mathrm{Tl})$, pour l'étude des glaciers et des sédiments. CEA (Commissariat à l'Énergie Atomique) Note 2756, 291-296.

Pinglot, J. F. and 8 others. 1994. Natural and artificial radioactivity in the Svalbard glaciers. 7. Environ. Radioactivity, 25(1), 161-176.

Pinglot, J. F., M. Pourchet, B. Lefauconnier and M. Creseveur. 1997. Equilibrium line and mean annual mass balance of Finsterwalderbreen, Spitsbergen, determined by in situ and laboratory gamma-ray measurements of nuclear test deposits. Ann. Glaciol., 24, 54-59.

Pinglot, J. F. and 6 others. 1999. Accumulation in Svalbard glaciers deduced from ice cores with nuclear tests and Chernobyl reference layers. Polar Res., 18(2), 315-321.

Pinglot, J. F., J. O. Hagen, K. Melvold, T. Eiken and C. Vincent. 2001. A mean net accumulation pattern derived from radioactive layers and radar soundings on Austfonna, Nordaustlandet, Svalbard. F. Glaciol., 47(159), $555-566$.

Pourchet, M., B. Lefauconnier, J. F. Pinglot andJ. O. Hagen. 1996. Mean net accumulation of ten glacier basins in Svalbard estimated from detection of radioactive layers in shallow ice cores. Z. Gletscherkd. Glazialgeol., 31, Part 1, 1995, 73-84.

Pourchet, M. and F. Pinglot. 1979. Determination of the stratospheric residence time from the total $\beta$ activity of Antarctic and Greenland snows. Geophys. Res. Lett., 6(5), 365-367.

Pourchet, M., J. F. Pinglot, L. Reynaud and G. Holdsworth. 1988. Identification of Chernobyl fall-out as a new reference level in Northern Hemisphere glaciers. 7. Glaciol., 34(117), 183-187.

Prantl, F. A., W. Ambach and H. Eisner. 1973. Alpine glacier studies with nuclear methods. International Association of Scientific Hydrology Publication 107 (Symposium at Banff 1972 - The Role of Snow and Ice in Hydrology), Vol. 1, 435-444.

Punning, Ya.-M. K., T. A. Martma, K. E. Tyugu, R. A. Vaikmäe, M. Pourchet and F. Pinglot. 1986. Stratification in an ice core from Vestfonna, Nordaustlandet. Polar Geogr. Geol., 10(1), 39-43. (Translated from Mater. Glyatsiol. Issled. 52, 1985, 202-205)

Suzuki, T. and Y. Fujii. 1992. Verical profile of ${ }^{210} \mathrm{~Pb}$ in an ice core from the Høghetta ice dome in Spitsbergen. Proc. NIPR Symp. Polar Meteorol. Glaciol. 6, 84-87.

Suzuki, T., K. Ohta and O. Watanabe. 1995. Vertical distribution of ${ }^{210} \mathrm{~Pb}$ in the Arctic glacier, Snøfjellafonna, in northwestern Spitsbergen. Bull. Glacier Res. 13, 133-136.

Tarussov, A. 1992. The Arctic from Svalbard to Severnaya Zemlya: climatic reconstructions from ice cores. In Bradley, R.S. and P. D. Jones, eds. Climate since A.D. 1500. London and New York, Routledge, 505-516.

Theodórsson, P. 1977. 40-year tritium profiles in a polar and a temperate glacier. International Association of Hydrological Sciences Publication 118 (Symposium at Grenoble 1975 - Isotopes and Impurities in Snow and Ice), 393-398.

Uchida, T. and 7 others. 1996. Ice core analyses and borehole temperature measurements at the drilling site on Åsgårdfonna, Spitsbergen, in 1993. Natl. Inst. Polar Res. Mem., Special Issue 51, 377-386.

UK Atomic Energy Authority (UKAEA). 1957-97. Radioactive fallout in air and rain. Harwell, UK Atomic Energy Authority, (formerly Atomic Energy Research Establishment). (Annual reports from 1950 to 1970.)

Vaikmäe, R., Ya.-M. K. Punning, V. V. Romanov and N. I. Barkov. 1981. Stratifikatsiya lednikovogo kupola Vavilova na Severnoy Zemle pri pomoshchi izotopno-geokhimicheskikh metodov [Stratigraphy of the Vavilov ice dome in Severnaya Zemplya using isotopic geochemical methods]. Mater. Glyatsiol. Issled. 40,127-135

Watanabe, O. and 7 others. 2001. Studies on climatic and environmental changes during the last few hundred years using ice cores from various sites in Nordaustlandet, Svalbard. Nat. Inst. Polar Res. Mem., Special Issue 54, 227-242.

Winther, J.-G., O. Bruland, K. Sand, A. Killingtveit and D. Marechal. 1998. Snow accumulation distribution on Spitsbergen, Svalbard, in 1997. Polar Res., 17(2), 155-164.

Wright, S. M., B. J. Howard, P. Strand, T. Nylén and M. A. K. Sickel. 1999 Prediction of ${ }^{137}$ Cs fall-out from atmospheric nuclear weapons tests within the Arctic. Environ. Pollut., 104, 131-143.

Zagorodnov, V. S., O. L. Klementyev, N. N. Nikiforov, V. I. Nikolaëv, L. M. Savatyugin and V. A. Sasunkevich. 1990. Gidroterminicheskiy rezhim i l'doobrazovaniye v tsentral'noy chasti lednika Akademii Nauk na Severnoy Zemle [Hydrothermal regime and ice formation in the central part of the Akademiya Nauk glacier, Severnaya Zemlya]. Mater. Glyatsiol. Issled. $70,36-43$ 